\title{
Investigations on Terminalia arjuna Fruits: Part 2- Isolation of Compound from ethyl Acetate Fraction
}

\author{
M. Zahurul Haque•, ${ }^{a}$ M. Abdullah As Saki, ${ }^{b}$ M. Umar Ali, ${ }^{b}$ M. Yusuff Alib and \\ M. Abdullah-Al Maruf ${ }^{b}$ \\ ${ }^{a}$ BCSIR Laboratories, Rajshahi-6206 and ${ }^{b}$ Department of Chemistry, Rajshahi University, \\ Rajshahi-6205, Bangladesh
}

\begin{abstract}
Arjun (Terminalia arjuna) is used in traditional medicines for the treatment of various diseases (Ahmed, 2002). The phyto-chemical studies shows that the plant contains active and medicinal principles like glycosides, alkaloids, steroids, tennins etc (Ahmed, 2002). The chemical examinations of its fruits were taken up to isolate and identify active principles. For this purpose fresh fruits of Terminalia arjuna were extracted with rectified spirit. The extract was then triturated with ethyl acetate, which was then subjected to column chromatographic separation followed by PTLC. Such separation led to the isolation and purification of compound, sitosteryl-3-o-ß-Dglucoside. The structure of compound was characterized by IR, ${ }^{1} \mathrm{H}-\mathrm{NMR}$ and ${ }^{13} \mathrm{C}$ NMR spectroscopic studies.
\end{abstract}

Key words : Arjun, Phyto-chemical studies, Sitosteryl, Glucosidy, Chromatographic separation.

\section{Introduction}

It is worth to mention that life is directly or indirectly dependent on the vegetable kingdom for sustenance. Though some plants found in nature are poisonous but there are some plants, which serve us as source of energy and effective drugs. The natural products such as vitamins, hormones, antibiotics, and analgesics extracted from plants and animal tissues are very important for their medicinal uses. Different traditional systems of medicine have been developed in this region of the world based mainly on the use of the medicinal plants. Of these two impor- tant ones are the Ayurvedic and the Unani systems. People used these medicinal plants to alleviate the suffering of their body and mind from time immemorial. Medicinal plants mainly used in the preparation of Unani and Ayurbedic medicine, also prescribed by practitioners of traditional medicine in different parts of the country and others are used as household remedies by the common people. A number of plants used by the Hakims, Kabirages and Viadays may contain toxic constituents, which have some 
health hazard associated with them and may sometimes cause serious sufferings. In this situation a systematic investigation on the available plant resources is more important. Here one thing is very encouraging to note that our country abounds with a vast majority of medicinal plants and herbs. The availability of medicinal plants demands a systematic investigation on the isolation, purification and characterization of physiologically active principles, which are actually useful for the treatment of various diseases. So, efforts have been made to investigate Terminalia arjuna, a medicinal plant available in Bangladesh. The plant Terminalia arjuna is a herbaceous plant. It grows inadequately almost in every district of Bangladesh. It is a large deciduous, evergreen tree attaining a height of 60-80 ft, with a spreading crown and drooping branches. It is planted in many parts for shade and ornament. Terminalia arjuna belongs to the genus Terminalia and family Combretaceae and locally known as "Arjun gachh" (Ghani 1998). The plant acts as an gastroprotective (Devi et al. 2007), anti-mutagenic (Kaur et al. 2002), coronary artery disease (Dwivedi et al. 1997) etc. In continuation of our previous work on the petroleum ether extract of Terminalia arjuna fruits (Haque et al. 2007), we now report herein the isolation of some other compounds from ethyl acetate extract of same Terminalia arjuna fruits. The present paper describes with the same.

\section{Materials and Methods}

\section{Extraction of the fruits of Arjuna with rectified} spirit

The powders of the fruits $(4 \mathrm{Kg}$ ) were immersed in distilled rectified spirit $(10 \mathrm{~L})$ at room temperature for 48 hours. The extract was collected and the process of extraction was repeated five times more with fresh rectified spirit (5 L) until the extract become almost colorless. The extracts were combined and concentrated by removal of the solvent in a rotary evaporator under reduced pressure at a temperature below $45^{\circ} \mathrm{C}$. A greenish gummy mass was obtained and was denoted as R.

\section{Preliminary fractionation of the crude extract, $\mathbf{R}$}

The concentrated rectified spirit extract; $\mathrm{R}$ was extracted with petroleum ether (200 ml). The petroleum ether layer was of greenish colour and separated with the help of a separatory funnel and extraction was repeated for five times more. Total amount of pet. ether used for extraction was $1 \mathrm{~L}$.

The residual rectified spirit extract $\mathrm{R}$ was then extracted with ethyl acetate $(200 \mathrm{ml})$ five times at room temperature and the ethyl acetate extracts were combined and evaporated to dryness under reduced pressure. Total amount of ethyl acetate used for extraction was $1.5 \mathrm{~L}$ The grayish ethyl acetate extract (3.5 g) was designated as mass RE. 


\section{Examination of ethyl acetate triturate mass-RE}

The grayish gummy mass RE (3.5 g) was soluble in ethyl acetate, acetone and methanol. TLC examination of the fraction on silica gel plates in different solvent systems showed the fraction to be a mixture of several compounds. The resolution was best done in a solvent mixture of petroleum ether: ethyl acetate (2:3), which showed two spots at $\mathrm{R}_{\mathrm{f}} 0.68$ and 0.42 with long tailing.

\section{Column chromatographic separation of mass RE}

Mass RE (3.5 g) was dissolved in ethyl acetate and then adsorbed in small quantity of silica gel. The adsorbed mass was evaporated to dryness under reduced pressure making it completely free from solvent. It was then carefully poured on the top of a column of silica gel made in petroleum ether: ethyl acetate (10:1). The column was eluted first with petroleum ether followed by a mixture of petroleum ether and ethyl acetate then with ethyl acetate and methanol successively with increasing polarity. Fractions of about $50 \mathrm{ml}$. portion were collected in each conical flask and examined separately on TLC plates. The result of the chromatographic separation is shown in Table I.

Table I. Column chromatographic separation of fraction RE

\begin{tabular}{|c|c|c|c|c|}
\hline $\begin{array}{l}\text { Collection } \\
\text { nos. }\end{array}$ & Eluting solvent & TLC examination & Observation & $\begin{array}{r}\text { Fraction } \\
\text { nos. }\end{array}$ \\
\hline $1-3$ & $\begin{array}{l}\text { Pet. ether :ethyl } \\
\text { acetate (10:1) }\end{array}$ & $\begin{array}{l}\text { One single spot } \\
\text { at } R_{\mathrm{f}} 0.78\end{array}$ & One pure compound. & $\mathrm{REF}_{1}$ \\
\hline $4-10$ & $\begin{array}{l}\text { Pet. ether :ethyl } \\
\text { acetate(5:1) }\end{array}$ & $\begin{array}{l}\text { Long tailing from } \\
\text { the base line. }\end{array}$ & $\begin{array}{l}\text { No good resolution, } \\
\text { mixture of compounds. }\end{array}$ & $\mathrm{REF}_{2}$ \\
\hline $11-22$ & $\begin{array}{l}\text { Pet. ether: ethyl } \\
\text { acetate (1:1) }\end{array}$ & $\begin{array}{l}\text { Spot near base line } \\
\text { with tailing. }\end{array}$ & $\begin{array}{l}\text { No good resolution; } \\
\text { mixture of compounds. }\end{array}$ & $\mathrm{REF}_{3}$ \\
\hline $23-25$ & Ethyl acetate $100 \%$ & $\begin{array}{l}\text { Tailing from } \\
\text { the baseline. }\end{array}$ & No good resolution. & $\mathrm{REF}_{4}$ \\
\hline $26-32$ & $\begin{array}{l}\text { Ethyl acetate : } \\
\text { methanol (10:1) }\end{array}$ & $\begin{array}{l}\text { One major spot at } R_{f} 0 \\
33 \text { with small tailing }\end{array}$ & $\begin{array}{l}\text { One major compound } \\
\text { with negligible impurities }\end{array}$ & $\mathrm{REF}_{5}$ \\
\hline $33-38$ & $\begin{array}{l}\text { Ethyl acetate : } \\
\text { methanol }(5: 1)\end{array}$ & $\begin{array}{l}\text { Tailing from the } \\
\text { base line. }\end{array}$ & No good resolution. & $\mathrm{REF}_{6}$ \\
\hline $39-50$ & $\begin{array}{l}\text { Ethyl acetate: } \\
\text { methanol (3:1) }\end{array}$ & $\begin{array}{l}\text { Tailing from the } \\
\text { base line. }\end{array}$ & No good resolution. & $\mathrm{REF}_{7}$ \\
\hline
\end{tabular}




\section{Examination of fraction $\mathbf{R E F}_{1}$}

Fraction $\mathrm{REF}_{1}$ (10 mg) was a white waxy solid substance. It was soluble in petroleum ether, chloroform and ethyl acetate. It gave a single spot on TLC plate at $\mathrm{R}_{\mathrm{f}} 0.78$ using petroleum ether: ethyl acetate (10:1). The compound was designated as TE-1. It melted at $87-89^{\circ} \mathrm{C}$.

Examination and purification of fraction $\mathbf{R E F}_{5}$

Fraction $\mathrm{REF}_{5}$ (63 mg) showed one major spot at $\mathrm{R}_{\mathrm{f}} 0.33$ in ethyl acetate: methanol (10:1). It was made concentrated at reduced pressure and allowed to stand at room temperature for over night. An almost colorless crystalline compound was separated out from the green colored viscous mother liquid. The crystals were isolated and washed with ice-cold ethyl acetate when the major portion of green coloured impurities was removed. A light greenish crystalline compound was thereby obtained. It was then further purified by column chromatographic separation and showed a single spot at $R_{f}$ 0.33 in ethyl acetate: methanol (10:1). It was a white crystalline compound, melted at 287$288^{\circ} \mathrm{C}$ and was soluble in chloroform ethyl acetate and ethanol. It was designated as TE2.

\section{Results and Discussion}

Study on the fraction $\mathrm{REF}_{1}$ (compound TE-1)

The compound TE-1 was an amorphous solid, melting point, $87-89^{\circ} \mathrm{C}$ and was soluble in petroleum ether, chloroform and ethyl acetate and had $R_{f} 0.78$ in petroleum ether: ethyl acetate (10:1). The $1 \mathrm{R}$ spectrum of TA10 showed absorption band at $3478 \mathrm{~cm}^{-1}$ due to overtone of $\mathrm{C}=\mathrm{O}$ stretching frequency with that of $\mathrm{C}=\mathrm{O}$ stretching. Absorption bands at 2920 and $2848 \mathrm{~cm}^{-1}$ were due to C$\mathrm{H}$ asymmetric and symmetric stretching (Williams and Fleming 1988). Absorption band at $1733 \mathrm{~cm}^{-1}$ was due to $\mathrm{C}=\mathrm{O}$ group. Absorption bands at 1472 and $1375 \mathrm{~cm}^{-1}$ were due to $-\mathrm{CH}_{2}{ }^{-}$and $-\mathrm{CH}_{3}$ group. Absorption at $1272 \mathrm{~cm}^{-1}$ was due to $\mathrm{C}-\mathrm{O}$ stretching vibration.

The compound TE-1 was isolated in too small quantity to carry out further investigation, on it. So, it was not possible to elucidate the structure of the compound.

Study on the fraction $\mathrm{REF}_{5}$ (compound TE-2)

Fraction $\mathrm{REF}_{5}$ (42 mg) showed one major spot at $\mathrm{R}_{\mathrm{f}} 0.33$ in ethyl acetate: methanol (10:1) with minor impurities. Passing through a small column of silica gel then purified it. The sub-fraction gave a single spot on TLC plate. The pure compound was 
designated as TE-2. The compound TE-2 was a white crystalline compound, melting point, $283-286^{\circ} \mathrm{C}$ and was soluble in chloroform, ethyl acetate and methanol. It positively responded to Salkowsky and LibermannBurchard colour reaction showed its steroidal nature and also gave positive tests of carbohydrate (Molisch's test), which indicated the glucoside nature of the compound (Bahl et al. 1994).

The 1R spectrum of TE-2 showed absorption band at $3460 \mathrm{~cm}^{-1}$ for -OH stretching. Absorption bands at 2920 and $2849 \mathrm{~cm}^{-1}$ were due to presence of $\mathrm{C}$-H (aliphatic) asymmetric and symmetric stretching respectively. The absorption bands at 1458 and $1366 \mathrm{~cm}^{-1}$ showed the presence of methyl $\left(-\mathrm{CH}_{3}\right)$ and methylene $\left(-\mathrm{CH}_{2}-\right)$ group. The absorption frequency at $1021 \mathrm{~cm}^{-1}$ indicated $(>\mathrm{C}-\mathrm{O}-\mathrm{C}<$ ) structural feature in the compound. The absorption band at 1655 $\mathrm{cm}^{-1}$ ( $\mathrm{C}=\mathrm{C}$ stretching) along with the band at $800 \mathrm{~cm}^{-1}$ were due to the presence of trisubstituted double bond $(>\mathrm{C}=\mathrm{CH})$.

\section{The ${ }^{1} \mathrm{H}$-NMR spectrum of the compound TE-2}

The olefinic proton resonated as a broad singlet at $\delta 5.3 \mathrm{ppm}$, which indicated the presence of double bond in the ring system. The doublet at $\delta 4.34 \mathrm{ppm}$ (coupling constant $\mathrm{J}=7.76 \mathrm{~Hz}$ ) was for anomeric proton of sugar residue having $§$ linkage. The multiplet in the region of $\delta 3.19$ to 3.80 was due to oxygenated methine protons of sugar residue. Two signals at $\delta 0.61$ and $0.90 \mathrm{ppm}$ showed two methyl protons at C-18 and C-19 respectively. Two doublets and one singlet at $\delta$ 0.86, 0.76 and $0.72 \mathrm{ppm}$ showed the methyl protons of C-21, C-26 and C-27 respectively. A singlet at $\delta 0.74$ ppm was for methyl protons of C-29, which was attached to methylene group.

The ${ }^{13} \mathrm{C}-\mathrm{NMR}$ spectrum of the compound TE-2 in $\mathrm{CDCl}_{3}$ revealed the presence of 35 carbons. 29 signals were due to a skeleton and 6 signals for a sugar residue. A signal at $\delta 101.09 \mathrm{ppm}$ in the ${ }^{13} \mathrm{C}-\mathrm{NMR}$ spectrum showed anomeric carbon of the sugar residue in TE-2, which was linked, to the steroid aglycone part by ß-linkage. Three quaternary carbons C-5, C-10 and C-13 were assigned by the signals at $\delta 140.25,36.63$ and 42.34 respectively. The ${ }^{13} \mathrm{C}-\mathrm{NMR}$ data of the sugar residue was identical with that of the reported signals of glucose residue. The ${ }^{13} \mathrm{C}$ signals for each carbon atom of the identified compound TE-2 have been recorded by numbering the carbon atoms. Against each of the carbon numbers the ${ }^{13} \mathrm{C}$ values are tabulated in Table II. 
Table II. ${ }^{13}$ C-NMR data of TE-2 and that reported data of ß- sitosterol glucoside (Ahmed 2002)

\begin{tabular}{|c|c|c|c|}
\hline \multirow[t]{2}{*}{ Cabon number } & \multirow[t]{2}{*}{ Types of carbon } & \multicolumn{2}{|c|}{ Chemical shift in ppm } \\
\hline & & TE-2 & Sitosterol-ß- glucoside \\
\hline 1 & $-\mathrm{CH}_{2^{-}}$ & 37.25 & 37.52 \\
\hline 2 & $-\mathrm{CH}_{2-}$ & 29.64 & 30.31 \\
\hline 3 & $>\mathrm{CH}-$ & 79.22 & 78.75 \\
\hline 4 & $-\mathrm{CH}_{2-}^{-}$ & 39.76 & 40.05 \\
\hline 5 & $>\mathrm{C}=$ & 140.25 & 140.95 \\
\hline 6 & $=\mathrm{CH}-$ & 122.23 & 121.56 \\
\hline 7 & $-\mathrm{CH}_{2-}$ & 31.88 & 32.10 \\
\hline 8 & $>\mathrm{CH}-$ & 31.88 & 32.10 \\
\hline 9 & $>\mathrm{CH}-$ & 50.18 & 50.32 \\
\hline 10 & $>\mathrm{C}<$ & 36.73 & 36.93 \\
\hline 11 & $-\mathrm{CH}_{2-}$ & 21.06 & 21.31 \\
\hline 12 & $-\mathrm{CH}_{2^{-}}$ & 38.74 & 39.44 \\
\hline 13 & $>\mathrm{C}<$ & 42.34 & 42.42 \\
\hline 14 & $>\mathrm{CH}-$ & 56.75 & 57.03 \\
\hline 15 & $-\mathrm{CH}_{2-}$ & 24.29 & 24.51 \\
\hline 16 & $-\mathrm{CH}_{2-}$ & 28.24 & 28.42 \\
\hline 17 & $>\mathrm{CH}-$ & 56.04 & 56.23 \\
\hline 18 & $-\mathrm{CH}_{3}$ & 11.84 & 12.02 \\
\hline 19 & $-\mathrm{CH}_{3}$ & 19.32 & 19.41 \\
\hline 20 & $>\mathrm{CH}-$ & 36.16 & 36.35 \\
\hline 21 & $-\mathrm{CH}_{3}$ & 18.77 & 19.11 \\
\hline 22 & $-\mathrm{CH}_{2-}$ & 39.55 & 36.30 \\
\hline 23 & $-\mathrm{CH}_{2-}$ & 26.06 & 26.51 \\
\hline 24 & $>\mathrm{CH}-$ & 45.85 & 38.81 \\
\hline 25 & $>\mathrm{CH}-$ & 29.15 & 29.35 \\
\hline 26 & $-\mathrm{CH}_{3}$ & 19.79 & 19.20 \\
\hline 27 & $-\mathrm{CH}_{3}$ & 19.00 & 20.01 \\
\hline 28 & $-\mathrm{CH}_{2^{-}}$ & 23.07 & 23.14 \\
\hline 29 & $-\mathrm{CH}_{3}$ & 11.95 & 12.12 \\
\hline C-1' & $>\mathrm{CH}-$ & 101.09 & 102.25 \\
\hline C-2' & $>\mathrm{CH}-$ & 73.55 & 75.02 \\
\hline C-3' & $>\mathrm{CH}-$ & 76.35 & 78.12 \\
\hline C-4' & $>\mathrm{CH}-$ & 70.14 & 75.02 \\
\hline C-5' & $>\mathrm{CH}-$ & 75.67 & 72.82 \\
\hline C-6' & $-\mathrm{CH}_{2^{-}}$ & 61.55 & 62.08 \\
\hline
\end{tabular}


The spectral data of compound TE-2 was matched very well with the reported data for sitosteryl-3-o-ß-D-glucoside (Ahmed 2002). Therefore the compound TE-2 was assigned as sitosteryl-3-o-ß-D-glucoside. The structure of the compound is given below:
Chemistry, Karachi University, Karachi, Pakistan.

Bahl, B.S. Bahl, A. (1994) Advanced Organic Chemistry, 833.

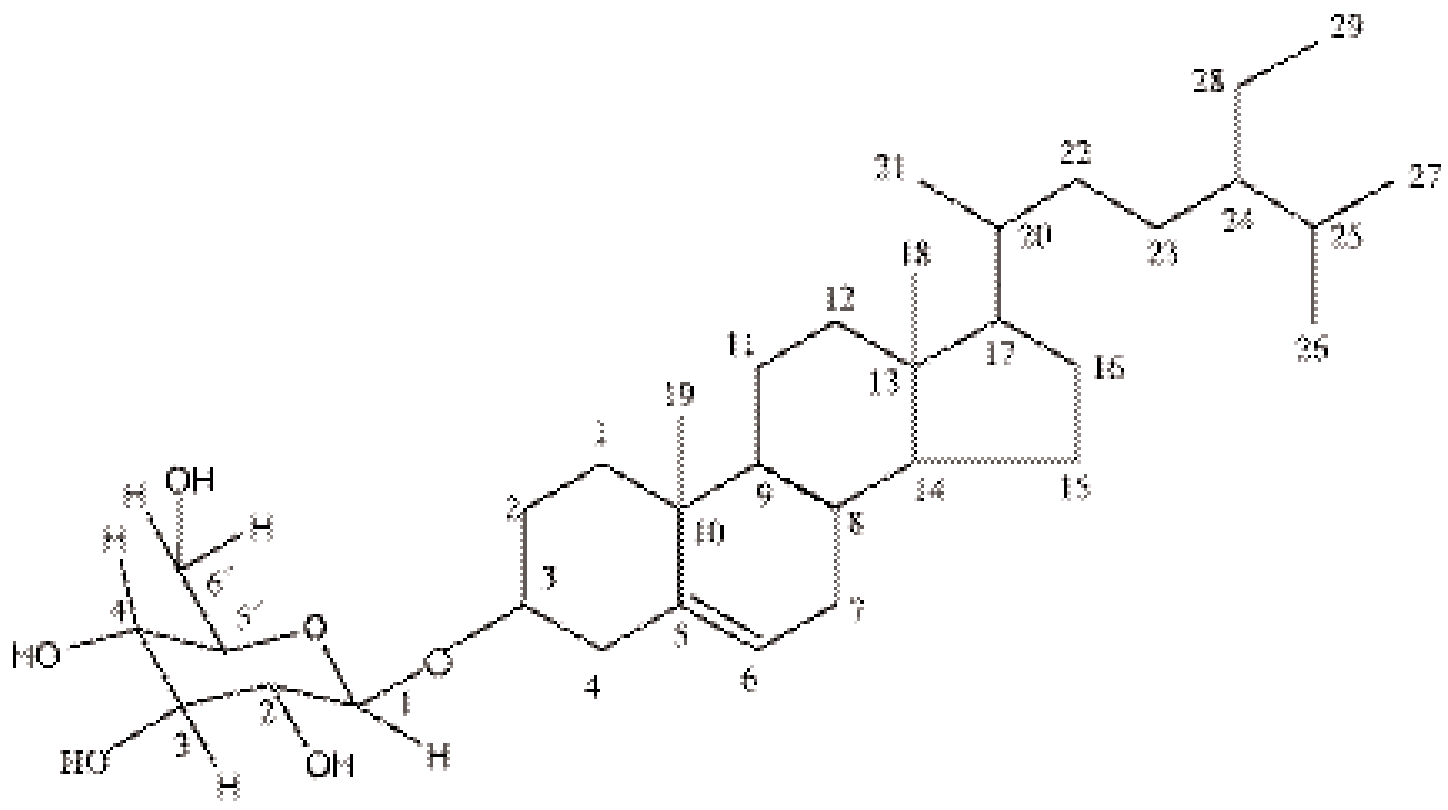

Sitosteryl-3-0- $\beta$-D-glucosode

\section{References}

Ahmed, M.S. (2002) The isolation and structural studies on some medicinal plants of Pakistan, Buxus papillosa, Catharanthus roseus and Cissampelos pareira. Ph.D Thesis, H.E.J. Research Institute of
Devi, R.S. Narayan, S. Vani, G. and Devi, C.S. (2007) Gastroprotective effect of Terminalia arjuna bark on diclofenac sodium induced gastric ulcer. Chem. Biol. Interact. 167(1): 41- 83.

Dwivedi, S. and Jauhari, R. (1997) Beneficial 
effects of Terminalia arjuna in coronary artery disease. Indian Heart J. 49(5): 507510.

Ghani, A. (1998) Medicinal Plants of Bangladesh, Chemical Constituents and Uses. Published by Asiatic Society of Bangladesh, pp 304.

Haque, M.Z. Saki, M.A. Ali, M.U. Ali, M.Y. and Maruf, M.A. (2007) Investigations on Terminalia arjuna fruits: Part 1- Isolation of compounds from petroleum ether fractions. Bangladesh J. Sci. Ind. Res.
Kaur, K. Kumar S. and Nagpal, A. (2002) Antimutagenic activities of acetone and methanol fractions of Terminalia arjuna. Food Chem. Toxicol. 40(1): 1475- 82.

Williams, D.H. and Fleming, I. (1988) Spectroscopic Methods in Organic Chemistry (4th Ed.), Tata -McGraw Hill, New Delhi, 40-62.

Received : Janu 27, 2005;

Accepted : September 08, 2006 